\title{
Influences of large-scale climatic variability on reindeer population dynamics: implications for reindeer husbandry in Norway
}

\author{
R. B. Weladji ${ }^{1, *}$, Ø. Holand ${ }^{2}$ \\ ${ }^{1}$ Département de Biologie, Université Laval, Sainte-Foy, Québec G1K 7P4, Canada \\ ${ }^{2}$ Department of Animal and Aquacultural Sciences, Norwegian University of Life Sciences, PO Box 5003, 1432 Ås, Norway
}

\begin{abstract}
There is increasing evidence that the globe is currently warming, with changes being more pronounced in northern latitudes. Understanding the ecological effects of climatic variability is therefore important. There is recent support for the idea that a large-scale atmospheric phenomenon, the North Atlantic Oscillation (NAO), through its effects on vegetation and regional weather conditions, influences several aspects of life histories and population dynamic processes of several mammal species, including reindeer Rangifer tarandus. However, patterns are inconsistent both between species and within species. Here, we focus on reindeer, a herbivore that inhabits an extremely seasonal environment. We review and discuss predicted patterns of global climatic change in Norway and assess potential consequences for reindeer husbandry. We argue that although it is clearly shown that local and global climate affect reindeer directly (e.g. increased energetic costs of moving through deep snow and in accessing forage through snow) and indirectly (e.g. effect on forage plant biomass and quality, level of insect harassment and associated parasitism), it is difficult to predict a general pattern of how future climate change will influence this species. It is especially difficult to predict how reindeer husbandry (an important economic and cultural activity for the Saami People) will be affected in Norway. Indeed, (1) patterns in life history traits and population parameters of reindeer vary over space and time, (2) both temperature and precipitation will increase in Norway, with greater changes in the North, i.e. the areas with reindeer husbandry, but the rate of increase will vary with space and seasons, (3) there are several indirect effects of global warming that can complicate the ecological response, especially involving the response of vegetation (e.g. forage on which reindeer depend), and (4) spatial variation, seasonality, complexity of the ecosystem functioning and nonlinearity of ecological processes make any firm prediction uncertain. Consequently, it is difficult to assess the practical and socio-economic implications for the reindeer husbandry industry.
\end{abstract}

KEY WORDS: Global warming $\cdot$ Population dynamics $\cdot$ Reindeer husbandry $\cdot$ Large-scale climatic variability $\cdot$ Temperature $\cdot$ Precipitation $\cdot$ North Atlantic Oscillation $\cdot$ Rangifer tarandus

\section{INTRODUCTION}

Discussions on the impact of climatic variations on ecological processes began many years ago (Elton 1924). In the growing interest to understand the importance of factors influencing the population dynamics of mammals, recent focus turned towards the importance of the variation in environmental conditions, including climate (Murdoch 1994, Turchin 1995, Putman et al. 1996, Sæther 1997). Although patterns have emerged,
Sæther (1997) argued that the effects of weather on the population dynamics of herbivores are only superficially understood. Indeed, climatic variation (local and global) has been reported to affect several life history and population parameters of large herbivores (see reviews by Putman et al. 1996, Post \& Stenseth 1999, Gaillard et al. 2000). However, effects vary, for example, with the structure of the population, including age, sex, and other individual attributes, as well as spatial and temporal factors (see Gaillard et al. 2003), and 
their interactions. For example, climatic variation may act through its interaction with density, with the effect usually being more pronounced at high densities (Coulson et al. 2001, Weladji 2003).

There has been an increasing use of large-scale climate indices such as the North Atlantic Oscillation (NAO) and the El Niño Southern Oscillation (ENSO) to study climatic effects in ecology (see Stenseth et al. 2003 for a review). The effects of such large-scale climate indices on both terrestrial and marine ecosystems are clearly established (reviews by Stenseth et al. 2002, Walther et al. 2002). For mammalian herbivores and particularly ungulates, the NAO (see reviews by Weladji et al. 2002 and Mysterud et al. 2003) and the Arctic Oscillation (AO; e.g. Aanes et al. 2002), 2 highly correlated indices (Thompson \& Wallace 1998) predominate. Both indices are large-scale alternation of atmospheric pressure, and the roles of the NAO index (Rogers 1984, Hurrell 1995, 1996) and the AO index (Thompson \& Wallace 1998, 2001) in local as well as hemispheric climate variability are well documented. Moreover, the NAO is reported to be a major component of global climate change (Hurrell 1995, 1996) and apparently predicts ecological processes better than local weather (Hallett et al. 2004).

There is increasing evidence that climate (mean and variability) is changing. It is also widely acknowledged that the globe is currently experiencing a warming trend, the changes being more pronounced in northern latitudes (Mann et al. 1999, IPCC 2001). An increase in variability in temperature and precipitation will certainly have implications on mammalian systems, with some already being observed (Walther et al. 2002), but our ability to predict such effects is limited. It is a challenge for ecologists to use past and present knowledge, in combination with predictions made by climatologists/meteorologists and geophysicists, on future climate trends, to predict and discuss potential ecological effects of global climate change. In this paper, we use reindeer Rangifer tarandus, a species inhabiting an extremely seasonal environment (Klein 1999), as a biological model. The present study presents a synthesis of potential impacts of global climate on reindeer husbandry in Norway. We first synthesized current knowledge regarding the effect of climate on reindeer. We then summarized predicted patterns of global climatic change in Norway and assess the potential consequences for the reindeer husbandry industry, following a brief background on reindeer husbandry in Norway. We continue with our potential to predict the impact of climate change on reindeer husbandry, concluding with suggestions for future research and management.

Reindeer husbandry in northern Fennoscandia has adapted over the past 300-500 yr (Skjenneberg \& Slagsvold 1968) in response to changes in ecological, social and institutional conditions for the land-use and livelihood of the Saami (i.e. the ethnic group traditionally practicing reindeer herding in Fennoscandia). The level of income for reindeer herders (from reindeer husbandry) is generally low in Norway (Økonomisk utvalg 2004); hence the industry is vulnerable to extrinsic factors such as climate change. The main source of income is commercial meat production (Økonomisk Utvalg 2004). The industry also serves as a cultural basis and producer of raw materials for Saami handicraft. The reindeer industry therefore has a profound importance for the cultural identity of the Saami people (Paine 1994).

\section{LARGE-SCALE CLIMATIC VARIABILITY EFFECTS ON REINDEER}

Reindeer are relatively selective foragers, following the phenology progression of the vegetation by movements, aggregation and dispersal (Skogland 1989). Changes occurring in the productivity or the phenology of the vegetation likely affect reindeer population dynamics and ecology. During the last $7 \mathrm{yr}$, we have investigated the influences of intrinsic factors, such as density dependence, and extrinsic factors, such as climatic variability (global climate measured by the NAO index, as well as local weather parameters), on the body mass (Weladji \& Holand 2003a, Weladji et al. 2003a,b) and sex ratio (Weladji \& Holand 2003b, Weladji et al. 2003c) of reindeer (Fig. 1). Long-term data was provided from Sør-Trøndelag and Hedmark as well as Nord-Trøndelag reindeer herding areas in Norway (Fig. 2). Using a large-scale climatic index, we show that for reindeer, unfavourable winter climate (i.e. high NAO index in the study area, characterized by warm and wet winters) has a negative effect on body mass (Weladji \& Holand 2003a) and leads to a decrease in the proportion of male offspring (Weladji \& Holand 2003b). These effects are amplified when population density increases. When looking at the interspecific level, a striking feature appears to be the 'synchronization' of these climatic effects over large scales and covariance between sympatric species such as sheep Ovis aries and reindeer (Weladji et al. 2003a), and even for allopatric species such as red deer Cervus elaphus and sheep (Mysterud et al. 2001).

When combining our results with those available in the literature (reviewed by Mysterud et al. 2003), the responses of northern ungulates to climatic variability as well as density vary in time and space. Thus, management strategies for sustainable use of the landscape and optimal production should be highly sitespecific. The relationship between large-scale climate indices and local weather is complex, varying greatly 


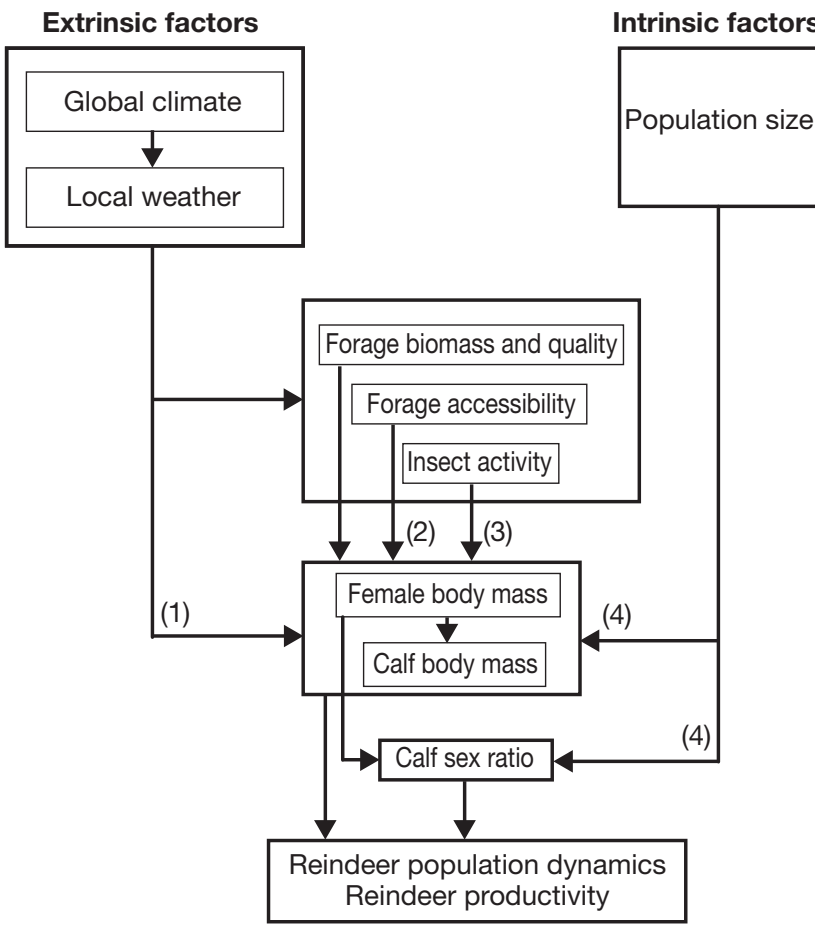

Fig. 1. Flow diagram summarizing results of our recent works relating climate to reindeer life history and population parameters. The diagram shows how reindeer population dynamics and productivity might be influenced by climate and population size. (1) Energetic costs of moving through deep snow, accessing forage through snow (cratering) and thermoregulation; (2) icing, deep snow; (3) insect harassment; (4) intraspecific competition. Note that density may also operate through its interaction with climate, and that population dynamics may also have a feedback effect on population size

with the topography (e.g. altitude), as well as the distance to the coast (NAO: Mysterud et al. 2000, Pettorelli et al. 2005a; AO: Tverra et al. unpubl.). It is also suggested that the most profound impact of increasing AO appears to be increased spatial heterogeneity in snow depth (Tverra et al. unpubl.). This leads to variable plant phenology across the landscapes, and hence to variable access to high quality forage by large herbivores (Mysterud et al. 2003) influencing their performance (Pettorelli et al. 2005a,b), and hence population dynamics. Therefore, assessment of the seasonal pattern is particularly important in northern environments where the growing season is short and highly variable. Accordingly, our recent works include, in addition to climatic indices, the NDVI (satellite-derived Normalized Difference Vegetation Index) that measures plant phenology more directly, and has been shown to be a useful tool with which to couple climate, vegetation and animal distribution and performance at large spatial and temporal scales (Pettorelli et al. 2005a). We show that the condition of animals in autumn is highly correlated to the start of the growing season (NDVI), the effect being as important as the winter effect (Pettorelli et al. 2005b). We previously found spring/summer range condition to be relatively more important for juvenile growth in reindeer than for example winter condition, but that the latter can greatly contribute to the overall pattern in a population (Weladji et al. 2003a), underlining complementarities in the seasonal effects. However, the pattern may be different if the winter is harsh or following extreme events as such as those occurring on Svalbard (Chan et al. 2005). Chan et al. (2005) revealed that continuous climate variability (e.g. Arctic Oscillation) and discrete extreme climatic events such as 'extreme icing' might have a dramatic effect on high arctic reindeer in Svalbard. Post \& Stenseth (1999) reported effects of the winter NAO index on reindeer calf body mass and adult female fecundity, while Aanes et al. (2002) showed that high values of the Arctic Oscillation index were associated with reduced plant growth and reindeer population growth rate in Svalbard.

These findings support the following views: (1) Patterns in life history traits, behaviour and population parameters of ungulates vary over space and time; (2) Extrinsic climatic fluctuations and population density, as well as their interaction, are important causative factors for the reported variations expressed by animals, their effects being mediated through nutri-

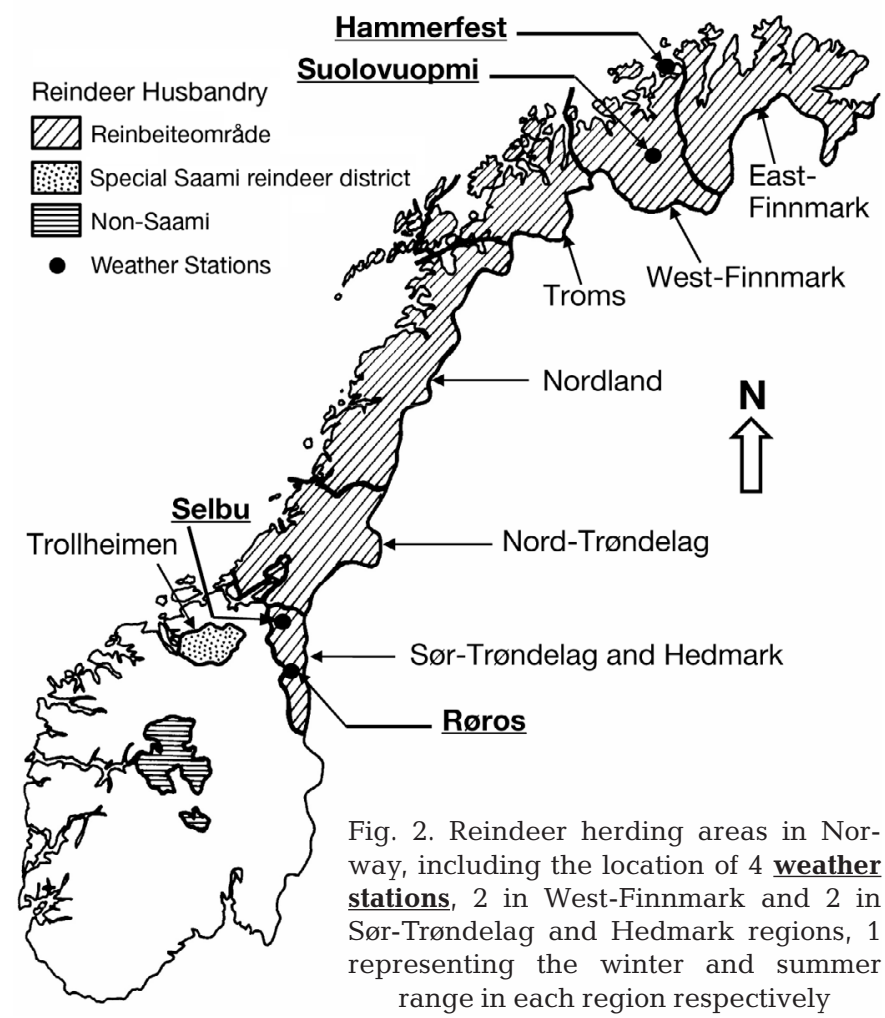


tional stress (e.g. increased intra-specific competition, indirect inter- and intraspecific competition, insect harassment, reduced forage quality and accessibility, and increased energy expenditure via foraging/locomotion in deep snow and thermoregulation); (3) Although reindeer are partly able to compensate negative environmental impacts through behavioral adjustment, global climate change might have considerable ecological implications, and hence may influence the reindeer husbandry industry.

\section{PREDICTED PATTERNS OF GLOBAL CLIMATIC CHANGE IN NORWAY}

The global climate is changing at a dramatic rate, with the average global temperature projected to increase 1.4 to $5.8^{\circ} \mathrm{C}$ over the course of this century (IPCC 2001). Hanssen-Bauer et al. (2003) downscaled the temperature scenario for Norway and concluded that warming rates will be higher in winter than in summer, inland than along the coast, and in the north than in the south, which accords with Benestad (2002). They reported predicted average warming of 1 to $2.5^{\circ} \mathrm{C}$ in various parts of the country up to the year 2050, but with variation between regions as well as seasons. Indeed, Hanssen-Bauer et al. (2003) found regional winter (December to February) warming rates of 0.3 to $0.6^{\circ} \mathrm{C}$ per decade, and summer (June to August) warming rates of 0.2 to $0.3^{\circ} \mathrm{C}$ per decade. Similar projections for precipitation showed an increase in an annual rate of 0.3 to $2.7 \%$ per decade in different Norwegian regions up to 2050 (Hanssen-Bauer et al. 2001, 2003), with seasonal as well as regional variations. The increase in precipitation is projected to be significant in all regions of Norway except the southeast. Significant increase in autumn precipitation is projected along the western coast of Norway, while a significant increase in winter precipitation is projected in southern parts of the country (Hanssen-Bauer et al. 2003). Roald et al. (2002) suggested a reduction in winter snow-cover in the lowlands all over Norway, while in the high mountains increasing snow amounts are projected, at least up to 2050 .

\section{BACKGROUND INFORMATION ON REINDEER HUSBANDRY IN NORWAY}

In Norway, reindeer are herded over an area of approximately $140000 \mathrm{~km}^{2}$ (about $40 \%$ of the country; Fig. 2). In 2005, about 2400 persons owned herds, constituting about 230000 reindeer (Reindriftsforvaltningen 2005). The 'Norwegian Reindeer Herding Act' provides the Saami exclusive right to practice reindeer husbandry. However, limited reindeer herding is practiced outside the main Saami pasture areas by nonSaami Norwegians (Fig. 2; southernmost hatched area), presently maintaining about 10000 animals. There are 6 administrative reindeer pasture regions (reinbeiteområde) (Fig. 2; oblique hatched area). The 2 northernmost reindeer pasture regions (i.e. East-Finnmark and West-Finnmark; Fig. 2) encompass about $2 / 3$ of the total reindeer population (Reindriftsforvaltningen 2005). They also practice a migratory system somewhat different from the rest of the country. When coupling Fig. 2 with the predictions for global climate change in Norway described in the previous section, it is clear that greater changes can be expected in the reindeer herding areas.

The reindeer husbandry in both East and WestFinnmark is characterized by a semi-nomadic grazing system, where the herds migrate from the lush summer range close to the coast to the interior winter range a distance of 100-350 km (Skjenneberg \& Slagsvold 1968). The summer grazing areas are characterized by mild summer climate with rather high precipitation (e.g. at the Hammerfest weather station, average summer [June-August] temperature was $10.0^{\circ} \mathrm{C}$ and precipitation $160 \mathrm{~mm}$, during the period 1961-1990; source: Norwegian Meteorological Institute [NMI], Oslo, Norway: see Fig. 2), whereas the winter ranges are characterized by winter temperatures well below freezing and little snow (e.g. at the Suolovuopmi weather station, average winter [January-March] temperature was $-12.4^{\circ} \mathrm{C}$ and precipitation was $80 \mathrm{~mm}$ during 1961-1990; source: NMI; see Fig. 2). The reindeer husbandry in Sør-Trøndelag and Hedmark, and Trollheimen, as well as in the non-Saami reindeer herding areas is more stationary with shorter migrations between their inland winter ranges characterized by low winter precipitation and stable low temperatures (e.g. at the Røros weather station, average winter temperature was $-8.8^{\circ} \mathrm{C}$ and average winter precipitation was $91 \mathrm{~mm}$ during 1961-1990; source: NMI; see Fig. 2) and their coastal summer ranges further west (Trollheimen and the non-Saami reindeer herding areas) and to the north in Sør-Trøndelag and Hedmark, characterized by mild and humid summers (e.g. at the Selbu weather station, the average summer temperature was $12.7^{\circ} \mathrm{C}$, and the average summer precipitation was $262 \mathrm{~mm}$ during 1961-1990; source: NMI; see Fig. 2). The winter ranges in the northernmost and southernmost regions are characterized by relative stable winter climate with a yearly variation in February snow depth of 15-30\% (Fauchald et al. 2004). In Troms, Nordland and Nord-Trøndelag, the limited winter ranges are normally coastal areas where the climate is mild due to the influence of the Gulf Stream and the winter precipitation is high and often comes as 
rain or sleet (Fauchald et al. 2004), rendering the ranges partly snow-free year-round. However, the variation in winter climate is pronounced, with a yearly variation in February snow depth of 30-70\% (Fauchald et al. 2004), indicating that at least occasionally, the snow depth in the coastal areas may be prominent in February, especially at higher elevations. In summer, the reindeer migrate short distances to the east into the mountain ranges. Within this coastalbound reindeer husbandry, we find many local adaptations based on high yearly climatic variability and finescale topographical as well as geological gradients.

\section{POTENTIAL CONSEQUENCES FOR REINDEER HUSBANDRY IN NORWAY}

As in all extensive animal production systems, the principal challenge is to transform the primary plant production into edible and other valuable products by efficient use of animals. The central tenet is to establish a balance between available seasonal grazing resources and the stocking rate. Variations in landscape, climate, and vegetation formations as well as in the socio-economical setting have triggered betweenregion adaptations in reindeer herding practices. Indeed, reindeer habitats throughout Norway may display high seasonal variability, while areas of large terrain variability may temper the local effects of climate change on vegetation and the patch dynamics of plant community structure, thereby influencing the quality of habitat for reindeer. Moreover, plant productivity as well as phenology depends on temperature and precipitation, in combination with other weather variables such as humidity, and yet both the mean and the variability of temperature and precipitation are expected to change (IPCC 2001). Several indirect effects of global warming are thus expected.

The abundance and quality of forage will be influenced, with consequences on reindeer condition through their effects on food supply. In warm winters, precipitation may fall at the coast in the form of rain rather than snow, and such reduction in snow cover will increase the winter forage accessibility and will probably favor the winter coastal-adapted reindeer husbandry along the coast south of Finnmark (Fig. 2), which is presently suffering from poor winter ranges (Fauchald et al. 2004). On the other hand, the projected increase in snowfall in higher elevated and mountainous areas may be harmful for those reindeer spending winters there, as access to lichen, their major winter forage, will be reduced. Moreover, increased precipitation as rain and sleet during calving will drain the newborn calves of heat, since the insulation property of wet pelages is greatly reduced (Cuyler
\& Øritsland 2004). The calves' limited ability to thermo-regulate due to limited body reserves and high surface area to body mass ratios can lead to reduced neonatal survival.

According to ACIA (2004), climate change will also lead to an increase in freezing rain and freeze-thaw cycles. These cycles will increase the frequency of icing at higher elevations and reduce the winter forage accessibility, thereby amplifying the negative effect of increased snow accumulation, and could reduce the winter carrying capacity, both in Finnmark and the southern reindeer herding areas (Fig. 2). Overall, reindeer husbandry in Finnmark, where production per head in most of the area is generally low and highly fluctuating (Reindriftsforvaltningen 2005), may benefit from the ongoing warming trend through an improved summer and autumn condition. Moreover, mushrooms are an important food source for reindeer during autumn (Staaland \& Nieminen 1993) and may increase in abundance due to improved conditions for growth in wet late summers.

Variation in timing of snowmelt will influence plant phenology, and plants may bloom earlier following warm and wet winters (Post \& Stenseth 1999). This may lead to a longer and warmer growing season. However, this would also favor the increase in the distribution range or a northward shift in vegetation zones, reducing the area of tundra and the traditional forage for these herds (ACIA 2004). However, the sum of many factors may threaten their adaptive capacity (ACIA 2004) through for example a disruption of their phenology or their interaction with the environment (i.e. occurrence of mismatch to the environment; see Stenseth \& Mysterud 2002 and Durant et al. 2005 for details on the match-mismatch hypothesis related to climate change). The predicted increase in growing season could also promote the expansion of agriculture in northern Fennoscandia. The ultimate limiting factor for the reindeer industry is access to grazing lands. Historically, agricultural settlements played a major role in displacing reindeer herders from their land (Fjellheim 1999). Current changes in land-use practice are increasingly incompatible with the preservation of the range, and the development of modern infrastructure results in land being irreversibly transformed. Additional changes in patterns of land use due to global warming include forestry, agricultural and industrial development, and expansion of tourism development. These all impose potential constraints on reindeer through an influence on their distribution and range use (see review by Weladji \& Forbes 2002).

Global warming might lead to warming soils and concomitant increase in nutrient cycling (Chapin et al. 1995). Such increase could cause long term change in species composition within the tundra ecosystems, 
with fast growing species possessing a high nutrient requirement becoming predominant (Berendse \& Jonasson 1992). Such a change in species composition might affect reindeer adversely by creating competition with browsing ungulates and reducing the lichen ranges. An increase in e.g. Lapland dwarf cornel Cornus suecica and mosses has been observed in recent years, while typical heath species such as crowberry Empetrum hermaphrodicum, bilberry Vaccinium myrtillus and reindeer lichens have decreased (Tømmerik et al. 2004). This could lead to a reduction in the quality of winter pastures for reindeer, and thus negatively affect reindeer husbandry. However, reindeer have evolved in highly seasonal, stochastic, and limiting natural environments, with low productivity. Therefore, reindeer may certainly overcome some of the stress caused by a shift to a more productive environment, unless out-competed by some of the more southerly forest dwelling species such as moose Alces alces, red deer Cervus elaphus or roe deer Capreolus capreolus that have already expanded north during the last decades (Mysterud 2000). As the climate gets progressively warmer in the north, large areas of open mountains would likely become gradually forested (Thannheiser et al. 2003). In addition, warmer summers may increase the reindeer burden of insect harassment (and thereby reduce their autumn condition; Colman et al. 2003, Weladji et al. 2003b), but this can also vary locally depending on wind speed and the topography, i.e. availability of insect relief (Weladji et al. 2003b).

Large-scale climatic variation influences body mass and growth of reindeer calves (Weladji 2003). It is thus likely that in areas where high NAO winter indices indicate severe winters, global warming might have negative consequences on reindeer growth, and hence on their population dynamics (Weladji 2003). Indeed, the condition in autumn can have long-lasting effects on the cohorts' life history (e.g. Forchhammer et al. 2001, Gaillard et al. 2003), and yearling survival is important for an individual reproductive success, and hence the population dynamics of the population (Gaillard et al. 2000, 2003). During winters with extreme adverse weather conditions, there may be a need to consider exploring supplementary feeding as a buffer strategy to reduce the mortality (Nieminen et al. 1987). High winter mortality due to heavy snow accumulation, often in combination with heavy utilization of lichen ranges, has been reported several times from different areas of Norway during the 1900s (Skjenneberg \& Slagsvold 1968), most recently in Finnmark during the high snow-fall winters of 1997 and 2000 (Reindriftsforvaltningen 2005). An emergency feeding strategy may reduce such losses in the future. However, we think it is important for the industry to rely primarily on a year-round forage resource as a key to an ecologically sustainable meat production system. This requires seasonal range utilization to be balanced. The rangeland available for reindeer husbandry has been dwindling, and competition for control and use of the pasture resources will probably intensify during the coming decades. For the industry, it is essential to have control over the land in order to secure the seasonal grazing pasture as well as the migration routes. This can be achieved by preventing direct exploitation, but also by channeling human activities to minimize anthropogenic disturbance. Hence, maintaining flexibility (i.e. control of pasture resources) is critical for the industriy's capability to adapt to change in climatic conditions. Currently, legally acknowledged Saami land use rights are attached to reindeer husbandry as a mode of land use, and intermitted use has been taken as an basis for challenging their rights as demonstrated in several recent court trials in Norway (Bull 1997). The land use pattern of competing interests may also change as a consequence of climate change.

\section{CONCLUSION}

Implications of global climate on reindeer husbandry are manifold, and may lead to socio-economic conflicts (among or between herders and other land use strategies such as agriculture) and new ecological situations (e.g. response of reindeer will depend on response of vegetation, which will also depend on the interaction between climate and topography). We found that patterns in life history traits and population parameters in vary over space and time, and that causative factors include climate, density and their interaction. The effects of these causative factors are mediated through nutritional stress experienced by the animals. Given that the predicted changes in temperature and precipitation will vary with seasons and regions, it is therefore difficult to draw firm conclusions. There may be some compensation for adverse effects in one season by beneficial effects in other seasons, so that the average effect on an annual basis is not necessarily harmful. Indeed, a prerequisite for continued reindeer husbandry based on Saami land use rights is that the industry can be profitable enough to allow a sufficient number of the Saami reindeer herders to remain in business. This means an adequate body mass in autumn, which may be manipulated by optimal stocking rate. Adequate body mass in autumn is critical for the herders' economy the current year (improved production output), but it also increases the chance of having higher fecundity as well as higher winter survival in a given year, and hence would yield a surplus to harvest the year after. Larger calves in the autumn 
appear to be better able to withstand adverse effects of harsh weather compared to lighter calves (Tverra et al. unpubl.). This might induce selection for larger animals including artificial selection schemes that favour larger individuals for the breeding stock. To achieve this in areas where winter will be harsh enough to threaten population performance, reindeer herders should consider supplementary feeding in winter to secure adequate winter survival and reproductive performance the following summer.

The complexity of the ecosystem functioning may also render any firm conclusion difficult. Tight multitrophic interactions might be disrupted (trophic levels, competition, harvest strategies, etc.). Moreover, the ecological effects of climate variability might be nonlinear (Mysterud et al. 2001, Stenseth et al. 2002), and the probability of the occurrence of mismatch to the environment may increase, resulting in uncertainties associated with climate change predictions. Although reindeer are easy to herd and habituate quickly to new environments, climate change may constrain the original nomadic migration pattern and trigger new and local adaptations, including revision of district range boundaries. On a larger scale, the Norwegian-Swedish agreement for exchange grazing rights (Reinbeitekommisjonen 2001) may need to be made more flexible. The herdsmen often claim that climatic stochasticity is the driving force for biomass production and availability, and hence influences the dynamics of plant-herbivore interaction (non-equilibrium approach), and have questioned the managers' confidence in classical equilibrium theory. This mismatch in conception between managers and herders, particularly in Finnmark, has been accentuated by increased human activity and encroachment and increased predator pressure, the effect of these confounding factors being disputed.

Although uncertain, global climate change will have considerable ecological implications, including effects on reindeer population dynamics. However, the effects will vary in time and space, and several other direct and indirect effects will also follow, with variable levels of complexity. It is therefore difficult and uncertain to generalise or make long term predictions regarding how global warming will influence reindeer husbandry. It is interesting however to evaluate in a relatively shorter time scale how the observed effects match with the long-term predictions. There may be a need for an in-depth consideration of applying adaptive management approaches (Walters 1986) to reindeer husbandry in Norway, i.e. manipulation of population size to minimize the stochastic effect of climatic variation and adequate planning to minimize future effects of the current global warming trends, e.g. protection of key habitats including insect-relief habitat.
Acknowledgements. We are grateful to Nathalie Pettorelli, Anders A. Ims, Jean-Pierre Ouellet and 2 anonymous reviewers for their constructive comments. Thanks to Jonathan Colman for checking the English.

\section{LITERATURE CITED}

Aanes R, Sæether BE, Smith FM, Wookey PA, Øritsland NA (2002) The Arctic Oscillation predicts effects of climate change in two trophic levels in a high-arctic ecosystem. Ecol Let 5: 445-453

ACIA (Arctic Climate Impact Assessment) (2004) Impacts of a warming arctic: Arctic climate impact assessment. ACIA Overview report. Cambridge University Press, Cambridge

Benestad RE (2002) Empirically downscaled multi-model ensemble temperature and precipitation scenarios for Norway. J Clim 15:3008-3027

Berendse F, Jonasson S (1992) Nutrient use and nutrient cycling in northern ecosystems. In: Chapin FS III, Jefferies RL, Reynolds JF, Shaver GR, Svoboda J (eds) Arctic ecosystems in a changing climate: an ecophysiological perspective. Academic Press, San Diego, CA, p 337-356

Bull KS (1997) Studier i reindriftsrett. Tano Ascehoug, Otta, Norge (in Norwegian)

Chan KS, Mysterud A, Øritsland NA, Severinsen T, Stenseth NC (2005) Continuous and discrete extreme climatic events affecting the dynamics of a high arctic reindeer population. Oecologia 145:556-563

Chapin FS, Shaver GR, Giblin AE, Nadelhoffer KJ, Laundre JA (1995) Responses of Arctic Tundra to experimental and observed changes in climate. Ecology 76:694-711

Colman JE, Pedersen C, Hjermann DO, Holand Ø, Moe SR, Reimers E (2003) Do wild reindeer exhibit grazing compensation during insect harassment? J Wildl Manage 67: $11-19$

Coulson T, Catchpole EA, Albon SD, Morgan BJT, Pemberton JM, Clutton-Brock TH, Crawley MJ, Grenfell BT (2001) Age, sex, density, winter weather, and population crashes in Soay sheep. Science 292:1528-1531

Cuyler C, Øritsland NA (2004) Rain more important than wind chill for insulation loss in Svalbard reindeer fur. Rangifer 24:7-14

Durant JM, Hjermann DØ, Anker-Nilssen T, Beaugrand G, Mysterud A, Pettorelli N, Stenseth NC (2005) Timing and abundance as key mechanisms affecting trophic interactions in variable environments. Ecol Lett 8:952-958

Elton CS (1924) Periodic fluctuations in the number of animals: their cause and effects. Br J Exp Biol 2:119-163

Fauchald P, Tveraa T, Yoccoz NG, Ims RA (2004) En økologisk bærekraftig reindrift. Hva begrenser naturlig produksjon og høsting? NINA Fagrapport 76, Trondheim (in Norwegian)

Fjellheim S (1999) Samer i Rørostraktene. Saeminen Sietje, Namsen Trykk, Namsos (in Norwegian)

Forchhammer MC, Clutton-Brock TH, Lindström J, Albon SD (2001) Climate and population density induce long-term cohort variation in a northern ungulate. J Anim Ecol 70: 721-729

Gaillard JM, Festa-Bianchet M, Yoccoz NG, Loison A, Toïgo C (2000) Temporal variation in fitness components and population dynamics of large herbivores. Ann Rev Ecol Syst 31:367-393

Gaillard JM, Loison A, Toïgo C, Delorme D, Van Laere G (2003) Cohort effects and deer population dynamics. Ecoscience 10:312-320

Hallett TB, Coulson T, Pilkington JG, Clutton-Brock TH, 
Pemberton JM, Grenfell B (2004) Why large-scale climate indices seem to predict ecological processes better than local weather. Nature 430:71-75

Hanssen-Bauer I, Tveito OE, Førland EJ (2001) Precipitation scenarios for Norway. Empirical downscaling from ECHAM4/OPYC3. Klima Rep 10/01, Norwegian Meteorological Institute, Oslo

Hanssen-Bauer I, Førland EJ, Haugen JE, Tveito OE (2003) Temperature and precipitation scenarios for Norway: comparison of results from dynamical and empirical downscaling. Clim Res 25:15-27

Hurrell JW (1995) Decadal trends in North Atlantic Oscillation: regional temperatures and precipitations. Science 269:676-679

Hurrell JW (1996) Influence of variations in extratropical wintertime teleconnections on northern hemisphere temperature. Geophys Res Lett 23:665-668

IPCC (2001) Climate Change 2001: the third assessment report of the intergovernmental panel on climate change. Cambridge University Press, Cambridge

Klein DR (1999) The roles of climate and insularity in establishment and persistence of Rangifer tarandus populations in the high Arctic. Ecol Bull 47:96-104

Mann ME, Bradley RS, Hughes MK (1999) Northern hemisphere temperature during the past millennium: inferences, uncertainties, and limitations. Geophys Res Lett 26:759-762

Murdoch WW (1994) Population regulation in theory and practice. Ecology 75:271-287

Mysterud A (2000) Diet overlap among ruminants in Fennoscandia. Oecologia 124:130-137

Mysterud A, Yoccoz NG, Stenseth NC, Langvatn R (2000) Relationships between sex ratio, climate and density in red deer: the importance of spatial scale. J Anim Ecol 69: 959-974

Mysterud A, Stenseth NC, Yoccoz NG, Langvatn R, Steinheim G (2001) Nonlinear effects of large-scale climatic variability on wild and domestic herbivores. Nature 410:1096-1099

Mysterud A, Stenseth NC, Yoccoz NG, Ottersen G, Langvatn $R$ (2003) The response of the terrestrial ecosystems to climate variability associated with the North Atlantic Oscillation. In: Hurrell JW, Belgrano A, Ottersen G, Kushnir Y (eds) The North Atlantic Oscillations: climatic significance and environmental impact. American Geophys Union, Washington DC, p 235-262

Nieminen M, Pokka AS, Heiskari U (1987) Artificial feeding and nutritional status of semi-domesticated reindeer during winter. Rangifer 7:51-58

Økonomisk utvalg (2004) Totalregnskap for reindriftsnæringen. Reindriftsforvatningen, Alta (in Norwegian)

Paine R (1994) Herds of the tundra. A portrait of Saami reindeer pastoralism. Smithsonian Institute Press, Washington, DC

Pettorelli N, Mysterud A, Yoccoz NG, Langvatn R, Stenseth NC (2005a) Importance of climatological downscaling and plant phenology for red deer in heterogeneous landscapes. Proc R Soc Lond B 272:2357-2364

Pettorelli NP, Weladji RB, Holand $\varnothing$, Mysterud A, Breie $H_{\text {, }}$ Stenseth NC (2005b) The relative role of winter and spring conditions: linking climate and landscape-scale plant phenology to alpine reindeer performance. Biol Lett 1:24-26

Post E, Stenseth NC (1999) Climatic variability, plant phenology, and northern ungulates. Ecology 80:1322-1339

Putman RJ, Langbein J, Hewison AJM, Sharma SK (1996) Relative roles of density-dependent and density-independent factors in population dynamics of British deer. Mamm Rev 26:81-101
Reinbeitekommisjonen (2001) Innstilling fra den svensknorske reinbeitekommisjonen av 1997. Utenriksdepartementet, Oslo (in Norwegian)

Reindriftsforvaltningen (2005) Ressursregnskapet for reindriftsnæringen. Reindriftsforvaltningen, Alta (Report in Norwegian)

Roald LA, Beldring S, Væringstad T, Engeset R, Skaugen TE, Førland RJ (2002) Scenarios of annual and seasonal runoff for Norway based on climate scenarios for 2030-2049. Klima Rep 19/02, Norwegian Meteorological Institute, Oslo

Rogers JC (1984) The association between the North Atlantic Oscillation and the Southern Oscillation in the northern hemisphere. Mon Weather Rev 112:1999-2015

Sæther BE (1997) Environmental stochasticity and population dynamics of large herbivores: a search for mechanisms. Trends Ecol Evol 12:143-149

Skjenneberg S, Slagsvold L (1968) Reindriften og densnaturgrunnlag. Universitetsforlaget, Oslo (in Norwegian)

Skogland T (1989) Comparative social organisation of wild reindeer in relation to food, mates and predator avoidance. Adv Ethol 29:1-77

Staaland H, Nieminen M (1993) World reindeer herding: origin, history, distribution, economy. Proc 7th World Conf Anim Prod, Edmonton 1:161-203

Stenseth NC, Mysterud A (2002) Climate, changing phenology, and other life history traits: non-linearity and matchmismatch to the environment. Proc Nat Acad Sci USA 99: 13379-13381

Stenseth NC, Mysterud A, Ottersen O, Hurrell JW, Chan KS, Lima M (2002) Ecological effects of climate fluctuations. Science 297:1292-1296

Stenseth NC, Ottersen G, Hurrell JW, Mysterud A, Chan KS, Lima M, Yoccoz NG, Ådlandsvik B (2003) Studying climate effects on ecology through the use of climate indices: the North Atlantic Oscillation, El Niño Southern Oscillation and beyond. Proc R Soc Lond B 270:2087-2096

Thannheiser D, Tømmervik H, Wehberg J (2003) The vegetation changes and recent impact on mountain birch forest during the last 40 years. Hamburg Vegetationsgeogr Mitt $17: 48-49$

Thompson DWJ, Wallace JM (1998) The Arctic Oscillation signature in the wintertime geopotential height and temperature fields. Geophys Res Lett 25:1297-1300

Thompson DWJ, Wallace JM (2001) Regional climate impacts of the Northern Hemisphere annular mode. Science 293: 85-89

Tømmervik H, Høgda KA, Karlsen SR (2004) Growing season changes in Fennoscandia and Kola peninsula during the period 1982 to 2002 -implications for reindeer husbandry. Rangifer Rep 9:36-37

Turchin P (1995) Population regulation: old arguments and a new synthesis. In: Cappuccino N, Price PW (eds) Population dynamics: new approaches and synthesis. Academic Press, New York, p 19-40

Walters CJ (1986) Adaptive management of renewable resources. McMillan, New York

Walther GR, Post E, Convey P, Menzel A and 5 others (2002) Ecological responses to recent climate change. Nature 416:389-395

Weladji RB (2003) Climatic influences on the life history and population dynamics of a northern ungulate, Rangifer tarandus. PhD dissertation. Agricultural University of Norway, Ås

Weladji RB, Forbes BC (2002) Disturbance effects of human activities on Rangifer tarandus habitat: implications for life history and population dynamics. Polar Geogr 26: 171-186 
Weladji RB, Holand $\varnothing$ (2003a) Global climate change and reindeer: effects of winter weather on the autumn weight and growth of calves. Oecologia 136:317-323

Weladji RB, Holand $\varnothing(2003 b)$ Sex ratio variation in reindeer: a test of the extrinsic modification hypothesis. Wildl Biol 9:29-36

Weladji RB, Klein DR, Holand Ø, Mysterud A (2002) Comparative response of Rangifer tarandus and other northern ungulates to climatic variability. Rangifer 22:33-50

Weladji RB, Steinheim G, Holand $\varnothing$, Moe SR, Almøy T,

Submitted: November 2, 2005; Accepted: August 11, 2006
Ådnøy T (2003a) Temporal patterns of juvenile body weight variability in sympatric reindeer and sheep. Ann Zool Fenn 40:17-26

Weladji RB, Holand Ø, Almøy T (2003b) Use of climatic data to assess the effect of insect harassment on the autumn weight of reindeer (Rangifer tarandus) calves. J Zool 260: 79-85

Weladji RB, Holand $\varnothing$, Yoccoz NG, Lenvik D (2003c) Maternal age and offspring sex ratio variation in reindeer Rangifer tarandus. Annales Zoologici Fennici 40:357-363

Proofs received from author(s): September 21, 2006 